\title{
Frontoethmoidal mucocele presenting as proptosis
}

\author{
Wei-Chuan Shang Kuan, Chao-Chuan Chi
}

Department of Otolaryngology, Kaohsiung Veterans General Hospital, Kaohsiung, Taiwan

\section{Correspondence to} Dr Wei-Chuan Shang Kuan, melonkuan@gmail.com

\section{CrossMark}

\footnotetext{
To cite: Shang Kuan W-C, Chi C-C. BMJ Case Rep Published online: [please include Day Month Year] doi:10.1136/bcr-2013202733
}

\section{DESCRIPTION}

A 34-year-old man suffered from itching, burning and a foreign body sensation in his left eye for 6 months prior to his first ophthalmology clinic visit, where eye drops were prescribed for presumed keratitis without obvious improvement. Furthermore, his left eyelid was erythematous and swelling and tearing subsequently developed in the following 3 months. Aspiration and irrigation were performed at another clinic with short-term symptom relief. However, diplopia, visual impairment of the left eye and headache occurred in the past month, and he was referred to the local hospital for treatment. According to the previous medical history of chronic paranasal sinusitis following functional endoscopic sinus surgery, at our hospital on 26 July 2004, he was referred to our department for further evaluation. There was no systemic disease or trauma history, contact lens use or contaminated water exposure, and he denied symptoms of nasal obstruction, purulent discharge or anosmia. An ocular examination showed periorbital chemosis, oedema, exophthalmos, hypertelorism and ophthalmoplegia (figure 1A). Sinuscopy showed mild mucoid discharge over the left middle meatus. CT on 4 October 2013 revealed an expansile cystic lesion in the left anterior ethmoid and frontal sinus areas, with adjacent bony erosions and extension into the left medial and retrobulbar areas, favouring a mucocele (figure 2). Considering the rapid progression of symptoms and visual acuity loss, a revision endoscopic sinus surgery was performed for orbital decompression. ${ }^{1}$ The patient is currently receiving regular follow-ups with dramatic improvements compared with his initial presentation (figure 1B).
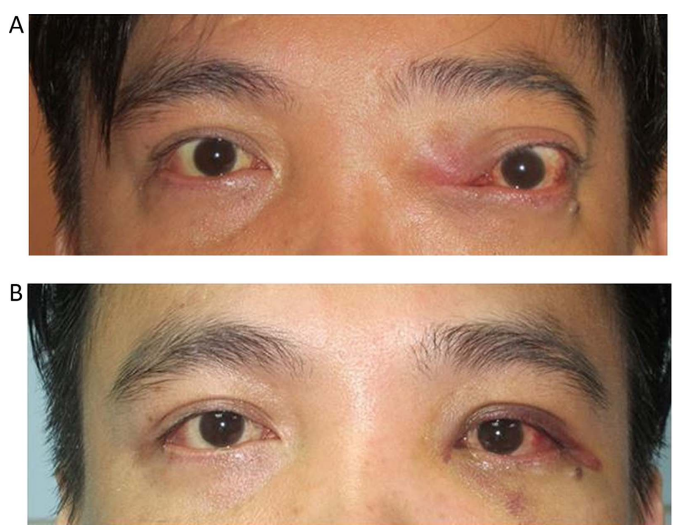

Figure 1 Photograph of ophthalmic evaluation. (A) Before operation: periorbital change over his left eye. (B) After operation: clinical improvement.

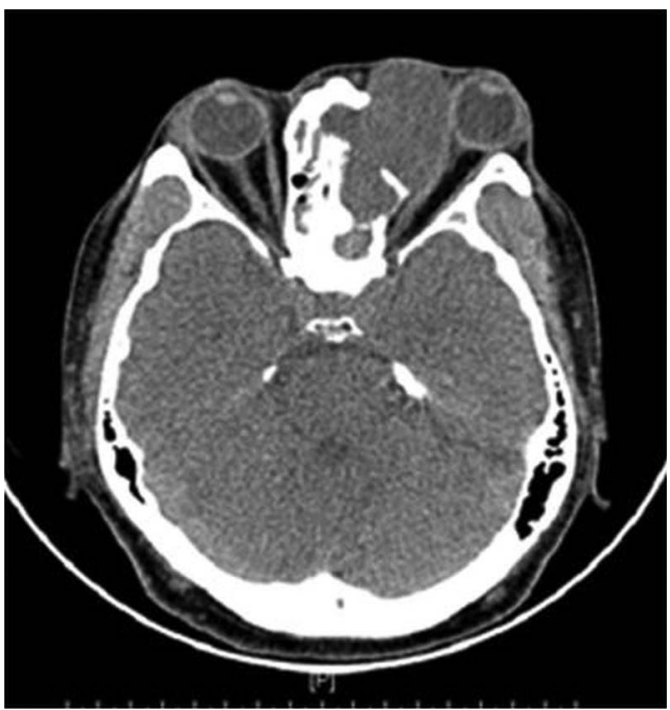

Figure 2 CT scan before operation. An expansile cystic lesion mainly at left anterior ethmoid and frontal sinus area $(5.4 \times 3.1 \times 4.6 \mathrm{~cm})$, with bony erosion and remodelling of left-side fovea ethmoidalis, cribriform plate, orbital walls (lamina papyracea, superior and inferior walls), medial maxillary sinus wall, anterior nasal septum and nasal bone, and extension to left nasal cavity and left medial and retrobulbar area, causing left-side anterior lateral exophthalmos.

\section{Learning points}

- Ophthalmic manifestations in patients with previous sinonasal disease must be evaluated clinically and radiographically with a suspicion for intranasal sources. ${ }^{2}$

- Endoscopic orbital decompression diminishes pressure within the orbit and causes globe recession from the mass effect of nearby structures. $^{3}$

- The prognosis for ophthalmic sequelae depends on the time from mucocele onset until surgery and the severity of visual impairment.

Contributors C-CC contributed in conception and design, analysis and interpretation of the data, critical revision of the article and final approval of the version to be published. W-CSK contributed in acquisition of data and drafting the article.

Competing interests None.

Patient consent Obtained.

Provenance and peer review Not commissioned; externally peer reviewed. 


\section{REFERENCES}

1 Courson AM, Stankiewicz JA, Lal D. Contemporary management of frontal sinus mucoceles: a meta-analysis. Laryngoscope. Published Online First: 12 Jul 2013. doi:10.1002/lary.24309
2 Tseng CC, Ho CY, Kao SC. Ophthalmic manifestations of paranasal sinus mucoceles. J Chin Med Assoc 2005;68:260-4.

3 Kasperbauer JL, Hinkley L. Endoscopic orbital decompression for Graves ophthalmopathy. Am J Rhinol 2005;19:603-6.

Copyright 2014 BMJ Publishing Group. All rights reserved. For permission to reuse any of this content visit

http://group.bmi.com/group/rights-licensing/permissions.

BMJ Case Report Fellows may re-use this article for personal use and teaching without any further permission.

Become a Fellow of BMJ Case Reports today and you can:

- Submit as many cases as you like

- Enjoy fast sympathetic peer review and rapid publication of accepted articles

- Access all the published articles

- Re-use any of the published material for personal use and teaching without further permission

For information on Institutional Fellowships contact consortiasales@bmjgroup.com

Visit casereports.bmj.com for more articles like this and to become a Fellow 